\section{BIBLIO COUNS}

Biblio Couns : Jurnal Kajian Konseling dan Pendidikan

Vol. 1, No. 3, November 2018, hlm. 79-88

Tersedia Online di jurnal.umsu.ac.id/index.php/biblio

ISSN 2620-3103 (online)

https://doi.org/10.30596/bibliocouns.v1i3.2236

\title{
Efektifitas Pendekatan Dicovery Learning dalam Bimbingan Kelompok Topik Tugas untuk Meningkatkan Kepercayaan Diri Mahasiswa Bimbingan dan Konseling
}

\author{
Asradi ${ }^{1}$, Freddi Sarman ${ }^{2}$ \\ Guidance and Counseling Study Program, University of Jambi, Indonesia. \\ Correspondence: Jl. Arif Rahman Hakim, Telanaipura, Jambi. \\ Email: asradimm@gmail.com ${ }^{1}$, freddisarman@gmail.com ${ }^{2}$
}

\section{Article Info \\ History of Article \\ Accepted Oktober 2018 \\ Approved Oktober 2018 \\ Published November 2018}

\begin{tabular}{l}
\hline Key Word \\
\hline Group Tutoring Service; \\
Discovery Learning; \\
Self Confidence.
\end{tabular}

\section{Citation Info}

Asradi. \& Sarman, F. (2018). Efektifitas Pendekatan Dicovery Learning dalam Bimbingan Kelompok Topik Tugas untuk Meningkatkan Kepercayaan Diri Mahasiswa Bimbingan dan Konseling. Jurnal Biblio Couns, 1(03), 79-88.

\begin{abstract}
This research aims to find out and prove the use of Discovery Learning approach through the tutoring service groups to increase confidence. This research using quantitative methods. This type of research is pre-experiments, using one group pretest posttest design. The selection of the subject using a purposive sampling method. The number of research subjects is ten people were selected according to the needs of research. The data were analyzed using statistical techniques nonparametrik that use the Wilcoxon Signed Ranks Test. The results showed that a score of pretest and posttest 77.5 was 101.8. Then to test hypotheses obtained results of Asymp. SIG (2-tailed) 0.0050 .005 , so < Ho can be interpreted is rejected and the $\mathrm{Ha}$ is received, it was concluded that no change or an increase in the confidence of students after being given the treatment of group guidance services using the approach of learning Discovery.
\end{abstract}




\section{PENDAHULUAN}

Kemampuan kognitif manusia merupakan salah satu hal yang membantu dalam pemecahan masalah dan pengambilan keputusan dalam setiap permasalahan yang dihadapi. Kemampuan kognitif manusia membentuk pemikiran rasional dan irasional yang menentukan dalam berperilaku, kemampuan kognitif manusia ini dibentuk dalam suatu pendidikan yang sistematis. Salah satu tujuan pendidikan adalah untuk membentuk pribadi yang mandiri, perguruan tinggi merupakan salah satu tempat dalam mencapai usaha untuk membentuk pribadi individu. Pendidikan di perguruan tinggi menuntut mahasiswa untuk aktif, kreatif, dan terampil dalam proses perkuliahan. Untuk menciptakannya adalah dengan berpendapat ataupun berbicara di kelas ketika diskusi dan bertanya terhadap dosen saat perkuliahan, namun pada kenyataannya keberanian berbicara atau berpendapat di depan umum tidak dimiliki semua mahasiswa. Rendahnya rasa percaya diri dapat mengganggu keefektifan kehidupan suhari-hari seperti: depresi, bunuh diri, dan masalah penyesuaian diri lainnya. Tingkat percaya diri yang rendah berhubungan dengan proses belajar atau kehidupan keluarga yang sulit, atau dengan kejadian-kejadian yang membuat tertekan. Suarni (2006: 133) menyatakan bahwa, dalam kehidupannya perilaku manusia dipengaruhi oleh dua faktor besar yaitu faktor internal dan faktor eksternal. Faktor internal adalah segala yang bersumber dari dalam diri siswa seperti; perhatian, kecerdasan, motivasi, sikap, berpikir, ingatan, percaya diri, minat, bakat serta kepribadian. Faktor eksternal meliputi masyarakat, keluarga dan sekolah.

Survey yang dilakukan oleh UCLA terhadap lebih dari 300.000 mahasiswa tingkat satu lebih dari 500 kampus ditemukan lebih banhak mahasiswa tingkat satu yang mengalami kewalahan dalam penyesuaian diri dengan dunia perkuliahan sehingga mengakibatkan stres (Santrock dalam Asyih, 109:2013). Berdasarkan pengalaman dan studi awal tersebut dapat disimpulkan bahwa terdapat masalah dalam proses pembelajaran dimana mahasiswa kurang kepercayaan diri dalam berbicara dan bertanya ini disebabkan ketakutan mahasiswa dalam mengungkapkan sesuatu didepan umum. Agar permasalahan tersebut dapat terentaskan maka peneliti mengangap perlu dalam menggunakan layanan bimbingan kelompok dengan teknik discovery learning. Penelitian terdahulu, Muhamad (2016) menghasilkan suatu temuan bahwa metode discovery learning dapat meningkatkan kemampuan representasi matematis dan pecaya diri siswa, Fiorentika, Santoso \& Simon (2016) dalam penelitiannya menghasilkan temuan bahwa siswa mengalami peningkatan kepercayaan diri setelah mengikuti konseling kelompok dengan teknik self-instruction, Suhardita (2011) dalam penelitiannya menghasilkan temuan bahwa penggunaan teknik permainan dalam bimbingan kelompok efektif digunakan untuk meningkatkan percaya diri siswa, selanjutnya penelitian Ramadhani, E. \& Sari, K. (2018) menunjukkan bahwa layanan bimbingan kelompok menggunakan pendekatan discovery learning efektif dalam mengurangi prokrastinasi akademik mahasiswa dalam mengerjakan skripsi, terkait dengan beberapa penelitian terdahulu, peneliti terkait mengkaji dari sisi penggunaan pendekatan discovery learning dalam bimbingan kelompok untuk meningkatkan kepercayaan diri mahasiswa.

Sund (dalam Suryosubroto, 2009:179) menyatakan pendekatan discovery learning adalah proses mental di mana siswa mengasimilasi suatu konsep atau suatu prinsip. Proses mental tersebut misalnya mengamati, mengelompokkan, membuat dugaan, mengukur, membuat kesimpulan, dan sebagainya. Selanjutnya, Ramadhani (2016:41) mengungkapkan bahwa pendekatan discovery learning adalah pembelajaran yang terjadi sebagai sebuah hasil dari kegiatan siswa dalam memanipulasi objek (alat peraga), membuat struktur, dan mentransformasikan informasi, sehingga menemukan informasi/pengetahuan tentang konsep baru. Berdasarkan hal tersebut, maka diperlukan ditingkatkan suatu bentuk sikap 
percaya diri dengan menggunakan pendekatan discovery learning dalam pelaksanaan bimbingan kelompok.

\section{METODOLOGI}

Jenis penelitian ini adalah penelitian kuantitatif dengan rancangan penelitian pre eksperimen, menggunakan desain tes awal (pretest) dan perlakuan terakhir (posttest). Rancangan eksperimen yang digunakan dalam penelitian ini adalah rancangan eksperimen model Pre Experiment, dengan pertimbangan bahwa masih terdapat variabel luar yang ikut berpengaruh terhadap variabel dipenden. Penelitian ini menggunakandesain penelitian The One Group Pretest-Posttest, desain ini digunakan untuk mengukur perubahan sebelum dan sesudah diberikan perlakuan. Penelitian ini dilakukan dengan memberikan pretest terlebih dahulu sebelum diberikan perlakuan dan diberikan postest setelah diberikan perlakuan. Pretest dilakukan untuk melihat kondisi awal subjek penelitian sebelum diberikan perlakuan dengan mbemberikan instrumen kepercayaan diri. Pada tahap berikutnya peneliti memberikan perlakuan berupa layanan bimbingan kelompok dengan pendekatan discovery learning. Pemberian perlakuan yang peneliti lakukan mengikuti tahap-tahap bimbingan kelompok, peneliti membantu mahasiswa menggali masalah-masalah yang berkaitan dengan kepercayaan diri. Durasi bimbingan kelompok disesuaikan dengan keinginan anggota kelompok dalam setiap kali pertemuan. Pada tahap akhir peneliti memberikan postest menggunakan instrumen kepercayaan diri untuk mengetahui keberhasilan selama pemberian perlakuan.

Pengumpulan data penelitian dilaksanakan dengan memberikan instrument kepercayaan diri kepada mahasiswa semester genap tahun ajaran (2017/2018) sejumlah 20 mahasiswa. Setelah pemberian instrumen peneliti memilih 10 orang mahasiswa bimbingan dan konseling angkatan 2017 yang dipilih sesuai dengan kriteria penelitian dengan metode purposive sampling. Alasan pengambilan dengan teknik purposive sampling agar relevan dengan tujuan penelitian dalam pendekatan discovery learning untuk meningkatkan kepercayaan diri mahasiswa. Adapun subjek penelitian ini adalah 6 orang yang memiliki kepercayaan diri yang rendah dan menambahkan 4 orang dengan kepercayaan diri cukup baik guna mencapai suatu syarat bentuk bimbingan kelompok yang baik, yaitu kelompok yang bersifat heterogenitas.

Tabel 1. Data Subjek Penelitian

\begin{tabular}{cccc}
\hline No. & Inisial & Angkatan & Kelas \\
\hline $\mathbf{1}$ & RDT & 2017 & $\mathrm{R}-001$ \\
\hline $\mathbf{2}$ & NBT & 2017 & $\mathrm{R}-001$ \\
\hline $\mathbf{3}$ & SCZ & 2017 & $\mathrm{R}-003$ \\
\hline $\mathbf{4}$ & TRNG & 2017 & $\mathrm{~N}-001$ \\
\hline $\mathbf{5}$ & MZM & 2017 & $\mathrm{~N}-001$ \\
\hline $\mathbf{6}$ & NDI & 2017 & $\mathrm{R}-002$ \\
\hline $\mathbf{7}$ & LCKY & 2017 & $\mathrm{R}-001$ \\
\hline $\mathbf{8}$ & OCN & 2017 & $\mathrm{R}-002$ \\
\hline $\mathbf{9}$ & KPR & 2017 & $\mathrm{R}-002$ \\
\hline $\mathbf{1 0}$ & RSDY & 2017 & $\mathrm{~N}-001$ \\
\hline
\end{tabular}

Dalam analisis data peneliti menggunakan teknik deskriptif yang menghasilkan tingkatan kategori kepercayaan diri sangat tinggi, tinggi, sedang, rendah dan sangat rendah. Sedangkan untuk pengujian hipotesis dilakukan dengan membandingkan tingkat kepercayaan diri subjek penelitian sebelum diberikan perlakuan dan setelah diberikan perlakuan, untuk lebih meyakinkan peneliti menggunakan analisis statistik dengan menggunakan uji Wilxocon denga bantuan SPSS. Hipotesis dinyatakan diterima jika nilai signifikansi $<0.05$ yang berarti terdapat perubahan atau meningkatnya kepercayaan diri 
setelah diberikan perlakuan layanan bimbingan kelompok melalui pendekatan discovery learning, namun jika nilai signifikansi $>0.05$ maka tidak terdapat perubahan atau meningkatnya kepercayaan diri setelah diberikan perlakuan layanan bimbingan kelompok melalui pendekatan discovery learning.

\section{HASIL}

Pelaksanaan kegiatan dilaksanakan dari bulan Maret 2018 sampai September 2018, kegiatan dilaksanakan diruangan lab konseling program studi Bimbingan dan Konselnig dengan 10 anggota kelompok yang terdiri dari enam orang mahasiswa yang memiliki kepercayaan diri rendah dan empat orang yang memiliki kepercayaan diri sedang. Sesuai dengan syarat untuk membuat suatu layanan bimbingan kelompok dimana anggota kelompok yang efisien adanya heterrogenitas, sehingga membantu anggota kelompok lain dan menciptakan suasana dinamika kelompok yang bagus. Secara spesifik penelitian ini untuk mengetahui penggunaan pendekatan Discovery learning dalam bimbingan kelompok topik tugas untuk meningkatkan kepercayaan diri mahasiswa.

\section{Kondiri Kepercayaan Diri Kelompok Eksperimen Sebelum Perlakuan (pretest)}

Data pretest berkaitan dengan kepercayaan diri mahasiswa berbicara di kelas, dapat dilihat pada tabel berikut:

Tabel 2. Hasil Pretest Kelompok Eksperimen tentang Kepercayaan Diri Mahasiswa Berbicara di Kelas

\begin{tabular}{cccc}
\hline \multirow{2}{*}{ No } & \multirow{2}{*}{ Inisial Nama } & \multicolumn{2}{c}{ Pretest } \\
\cline { 3 - 4 } & & Skor & Kategori \\
\hline $\mathbf{1}$ & RDT & 69 & Sedang \\
\hline $\mathbf{2}$ & NBT & 63 & Rendah \\
\hline $\mathbf{3}$ & SCZ & 64 & Rendah \\
\hline $\mathbf{4}$ & TRNG & 63 & Rendah \\
\hline $\mathbf{5}$ & MZM & 65 & Rendah \\
\hline $\mathbf{6}$ & NDI & 62 & Rendah \\
\hline $\mathbf{7}$ & LCKY & 98 & Tinggi \\
\hline $\mathbf{8}$ & OCN & 94 & Tinggi \\
\hline $\mathbf{9}$ & KPR & 97 & Tinggi \\
\hline $\mathbf{1 0}$ & RSDY & 100 & Tinggi \\
\hline
\end{tabular}

Berdasarkan jabaran tabel diatas, dapat dimaknai bahwa enam orang mahasiswa mengalami kondisi kepercayaan diri yang rendah dalam berbicara di kelas, yaitu RDT dengan skor 69, NBT dengan skor 63 , SCZ dengan skor 64, TRNG dengan skor 63, MZM dengan skor 65, NDI dengan skor 62 dan orang mengalami kondisi percaya diri yang bagus dengan inisial LCKY dengan skor 98, OCN dengan skor 94, KPR dengan skor 97 dan RSDY dengan skor 100.

\section{Kondiri Kepercayaan Diri Kelompok Eksperimen setelah Postest}

Data prostest berkaitan dengan kepercayaan diri mahasiswa berbicara di kelas, dapat dilihat pada tabel berikut: 
Tabel 3. Hasil Postest Kelompok Eksperimen tentang Kepercayaan Diri Mahasiswa Berbicara di Kelas

\begin{tabular}{cccc}
\hline \multirow{2}{*}{ No } & \multirow{2}{*}{ Inisial nama } & \multicolumn{2}{c}{ Pretest } \\
\cline { 3 - 4 } & & Skor & Kategori \\
\hline $\mathbf{1}$ & RDT & 98 & Tinggi \\
\hline $\mathbf{2}$ & NBT & 100 & Tinggi \\
\hline $\mathbf{3}$ & SCZ & 109 & Sangat Tinggi \\
\hline $\mathbf{4}$ & TRNG & 102 & Tinggi \\
\hline $\mathbf{5}$ & MZM & 97 & Tinggi \\
\hline $\mathbf{6}$ & NDI & 93 & Tinggi \\
\hline $\mathbf{7}$ & LCKY & 106 & Sangat Tinggi \\
\hline $\mathbf{8}$ & OCN & 109 & Sangat Tinggi \\
\hline $\mathbf{9}$ & KPR & 107 & Sangat Tinggi \\
\hline $\mathbf{1 0}$ & RSDY & 106 & Sangat Tinggi \\
\hline
\end{tabular}

Berdasarkan tabel diatas, dapat dimaknai bahwa enam orang mahasiswa mengalami kondisi cukup kepercayaan diri dengan kategori Sedang, yaitu RDT dengan skor 98, NBT dengan skor 100, SCZ dengan skor 109, TRNG dengan skor 102, MZM dengan Skor 97, NDI dengan skor 93, LCKY dengan skor 106, OCN dengan skor 109, KPR dengan skor 107 dan RSDY dengan skor 106.

\section{Perbedaan Hasil Prestest dan Postest Kondisi Kepercayan Diri Mahasiswa Berbicara di Kelas}

Sebelum melihat deskripsi perbedaan dari kepercayaan diri mahasiswa melalui pretest dan Postest, berikut tabel data pretest dan Postest.

Tabel 4. Perbedaan Hasil Pretest dan Postest Kelompok Eksperimen tentang Kepercayaan Diri Mahasiswa

\begin{tabular}{cccccc}
\hline \multirow{2}{*}{ No } & \multirow{2}{*}{ Inisial } & \multicolumn{2}{c}{ Pretest } & \multicolumn{2}{c}{ Postest } \\
\cline { 3 - 6 } & & Skor & Kategori & Skor & Kategori \\
\hline $\mathbf{1}$ & RDT & 69 & Sedang & 98 & Tinggi \\
\hline $\mathbf{2}$ & NBT & 63 & Rendah & 100 & Tinggi \\
\hline $\mathbf{3}$ & SCZ & 64 & Rendah & 109 & Sangat Tinggi \\
\hline $\mathbf{4}$ & TRNG & 63 & Rendah & 102 & Tinggi \\
\hline $\mathbf{5}$ & MZM & 65 & Rendah & 97 & Tinggi \\
\hline $\mathbf{6}$ & NDI & 62 & Rendah & 93 & Tinggi \\
\hline $\mathbf{7}$ & LCKY & 98 & Tinggi & 106 & Sangat Tinggi \\
\hline $\mathbf{8}$ & OCN & 94 & Tinggi & 109 & Sangat Tinggi \\
\hline $\mathbf{9}$ & KPR & 97 & Tinggi & 107 & Sangat Tinggi \\
\hline $\mathbf{1 0}$ & RSDY & 100 & Tinggi & 106 & Sangat Tinggi \\
\hline & Skor total & 775 & & 101,8 & \\
\hline & Rata- rata & 77,5 & Sedang & 101,8 & Tinggi \\
\hline
\end{tabular}

Pada skor keadaan kepercayaan diri mahasiswa pada pemberian pretest di dapati tiga kategori yaitu tinggi, sedang dan kurang, setelah diberikan perlakuan adanya bentuk perubahan dimana skor yang diperoleh dalam Postest sudah masuk kedalam kategori tinggi yang dapat dimaknai bahwa mahasiswa sudah menunjukkan suatu keadaan kepercayaan diri yang sangat bagus. Pada tabel di atas dapat di lihat bahwa mahasiswa NDI mengalami kondisi kepercayaan diri yang rendah dibanding teman-temanya dan setelah pemberian perlakuan kondisi yang di mungculkan dalam hasil Postest sudah menggambarkan kepercayaan diri yang baik. Dan mahasiswa SCZ mengalami meningkatan perubahan dalam pengolahan hasil Postest dengan peningkatan kepercayaan diri kategori sangat tinggi.

Untuk melihat perbedaan frekuensi kondisi kepercayaan diri masing masing kategori dari hasil pretest dan Postest dapan dijabarkan dari tabel berikut ini: 
Tabel 5. Distribusi Frekuensi Skor Pretest dan Postest Kelompok Experiment tentang Kepercayaan Diri di Dalam Kelas

\begin{tabular}{cccccc}
\hline \multirow{2}{*}{ Skor } & \multirow{2}{*}{ Kategori } & \multicolumn{2}{c}{ Pretest } & \multicolumn{2}{c}{ Postest } \\
\cline { 2 - 6 } & & F & $\%$ & F & $\%$ \\
\hline $\mathbf{2 1 0 6}$ & Sangat Tinggi & 0 & 0 & 0 & 0 \\
\hline $\mathbf{8 6 - 1 0 5}$ & Tinggi & 4 & 40 & 5 & 50 \\
\hline $\mathbf{6 6 - 8 5}$ & Sedang & 1 & 30 & 5 & 50 \\
\hline $\mathbf{4 6 - 6 5}$ & Rendah & 5 & 30 & 0 & 0 \\
\hline $\mathbf{4 5}$ & Sangat Rendah & 0 & 0 & 0 & 0 \\
\hline & Jumlah & 10 & 100 & 10 & 100 \\
\hline
\end{tabular}

Pada tabel di atas dimaknai bahwa dengan pemberian pendekatan discovery learning terdapat peningkatan kepercayaan diri mahasiswa dengan melihat perbedaan pretest dan Postest. Berdasarkan pengolahan menggunakan SPSS, perbedaan kepercayaan diri dapat dilihat pada tabel berikut ini:

Tabel 6. Gambaran Perbedaan Hasil Pretest dan Postest Kepercayaan Diri Mahasiswa di Kelas Descriptive Statistics

\begin{tabular}{llllll}
\hline & N & Mean & Std. Deviation & Min & Max \\
\hline Pretest & 10 & 77,5 & 17,161 & 62 & 100 \\
\hline Postest & 10 & 101,8 & 5,538 & 93 & 109 \\
\hline
\end{tabular}

\section{PENGUJIAN HIPOTESIS}

Pengujian hipotesis menggunakan uji wilxocon's skor pretest dan psotest dengan tujuan untuk membuktikan hipotesis penelitian. Apakah penggunaan layanan bimbingan kelompok menggunakan pendekatan discovery learning dapat meningkatkan kepercayaan diri jika nilai rata-rata rangking setelah diberikan perlkuan lebih tinggi dibandingkan nilai ratarata sebelum diberikan perlakuan dan hasil uji wilxoson menunjukkan perbedaan antara hasil pretest dan postes. Nilai wilxoson sebesar $\left(Z=-2,803^{\mathrm{a}}\right)$ dengan nilai Asymp. Sig. (2tailed) untuk uji dua sisi adalah 0.005. signifikansi dibawah $0.05(0.005<0.05)$ menunjukkan bahwa $\mathrm{H}_{0}$ ditolak, sehingga dapat disimpulkan bahwa layanan bimbingan kelompok dengan pendekatan discovery learning dapat meningkatkan kepercayaan diri mahasiswa.

\section{PEMBAHASAN}

\section{Kondisi Kepercayaan Diri Mahasiswa Berbicara di Kelas dalam Kelompok Eksperimen sebelum diberikan Perlakuan Pretest}

Kondisi gambaran kepercayaan diri mahasiswa berbicara di kelas atau didepan umum ketika perkuliahan berlangsung melalui hasil pretest yaitu 77,5 dengan kategori Sedang, berdasarkan hasil tersebut kondiri kepercayaan diri mahasiswa tergambar dari perilaku yang dimunculkan selama perkulihan yang telah peneliti amati selama proses perkuliahan terlihat kurangnya keaktifan mahasiswa tersebut, seperti kurangnya keaktifan mahasiswa selama perkulihan berlangsung, dan ketika berbicara dalam bentuk diskusi di depan kelas, mahasiswa cenderung kaku dan gugup dalam penyampaian materi, namun ada beberapa mahasiswa yang aktif dan leluasa dalam menyampaikan materi diskusi di depan teman-temannya. Keyakinan merupakan faktor penentu bagaimana individu bersikap dan bereaksi terhadap keadaan, segala tindakan dan perilaku yang dimunculkan mahasiswa itu seiring dengan keyakinan akan dirinya. Disamping itu bagai mana seorang mahasiswa dapat berinteraksi dengan lingkungan dan temannya itu membutuhkan suatu kepercayaan diri sehingga dapat nyaman di dalam perkuliahan dan berinteraksi (berdiskusi/berbicara) selama perkuliahan. Sebagaimana ditegaskan oleh Saputra (dalam Muhammad, 2016) "percaya diri adalah salah satu kunci kesuksesan siswa dalam belajar, karena apabila tidak ada ras percaya diri siswa tidak akan sukses dalam berinterasi dengan temannya".

Rendahnya kepercayaan diri yang muncul dari mahasiswa berawal dari pemikiran bahwa dirinya tidak mampu, tidak menguasi materi, penilaian dari dosen, dan ketika berbicara harus memiliki dasar sumber sehingga pertanyaan itu tidak dianggap melalukan. 
Kepercayaan seperti itu bermuara dari ketidak siapan mahasiswa akan pontensi akademiknya sehingga memicu rendahnya kepercayaan diri mahasiswa di kelas dan memilih untuk lebih baik diam dan menghindar. Maka dari itu mahasiswa akan sulit untuk tampil di depan kelas, karena percaya diri itu kondisi psikologi seseorang yang memberi pengaruh pada aktifitas fisik dan mental dalam proses belajar (Marjanti, 2015).

\section{Kondisi Kepercayaan Diri Mahasiswa Berbicara di kelas dalam Kelompok Eksperimen Sesudah Diberikan Perlakuan Postest}

Gambaran kondisi kepercayaan diri mahasiswa berdasarkan hasil Postest berada pada kategori tinggi atau 101,8 hasil tersebut diperoleh setelah setelah pelaksaan bimbingan kelompok dengan pendekatan discovery learning. Adapun kondisi kepercayaan diri yang rendah yang dimunculkan oleh siswa berupa ketidak percayaan diri dengan kemampuan dirinya, sehingga menghambat mahasiswa untuk dapat berkembang dan menyesuikan dengan keadaan lingkungan berkaitan dengan berbicara di kelas ketika perkuliahan berlangsung atau ketika berdiskusi di dalam perkuliahan. Suatu kepercayaan diri itu bisa dilatih dan dipelajari, sebagaimana Afiatin \& Martaniah (1998) mengatakan bahwa kepercayaan diri dapat ditumbuhkan dan ditingkatkan melalui penanaman sifat sifat percaya diri dengan belajar berperilaku yaitu perilaku percaya diri. Individu remaja atau mahasiswa yang mengalami kondisi kurang percaya diri membutuhkan pihak lain yang dapat mendorong keberaniannya dalam mengambil suatu keputusan, dan semua itu dapat dibantu dengan proses konseling salah satunya berupa layanan bimbingan kelompok.

Pelayanan yang diberikan berupa bimbingan kelompok ini bertujuan untuk melatih mahasiswa untuk dapat mengembangkan potensinya berua komunikasi atau berbicara di depan orang lain. Sehingga dengan dinamika yang dikembangkan dalam bimbingan kelompok ini diharapkan mahasiswa dapat melatih kepercayaan dirinya untuk beribcara di depan orang banyak. Adapun pendekatan discovery learning ini bertujuan untuk melatih siswa berfikir mendalam menemukan berbagai pola dalam situasi yang kongkrit maupun abstrak, sehingga mahasiswa dapat mengasosiasikan pola tersebut dan meramalkan informasi yang akan diberikan, dengan melatih mahasiswa dalam berfikir mendalam akan membantu mahasiswa ketika akan bertanya atau berdiskusi mereka dapat menyususn pertanyaan ataupun argumen yang kana disampaikan, sehingga membentuk argumen yang bagus yang akan disampaikan. Adapun pendekatan discovery learning ini merupakan suatu pendekatan yang digunakan dalam kurikulum 2013 yang secara efektif dapat membantu mahasiswa dalam mengasimilasi suatu konsep, menjelaskan ataupun membuat kesimpulan untuk membantu mahasiswa menghadapi kepercayaan dirinya yang lemah dalam berbicara di kelas perkuliahan. Sebagamana muhamad (2016) mempertegas bahwa "metode discovery learning pada dasarnya mengembangkan siswa belajar aktif karena mereka diarahkan untuk bisa menemukan sendiri suatu konsep yang nanatinya akan tahan lama dalam ingatan sehingga dengan sendirinya bisa membuat siswa percaya diri".

Dalam pelaksanaan kegiatan terungkap suatu pemikiran bahwa, takut berbicara karna takut salah dan tidak tau apa yang ingin di bicarakan ataupun yang akan di jawab dalam diskusi atau di dalam kelas. Sehingga apabila mereka takut ataupun tidak memiliki pertanyaan maupun jawaban, mereka akan memilih untuk diam. Pernyataan tersebut banyak diungkapkan oleh anggota bimbingan kelompok, sehingga apabila mereka menemui situasi tersebut mereka akan menghindarinya atau diam. Konsep ini lah yang membuat individu tidak berkembang, konsep tersebut tertanam karena ketidak percayaan terhadap kualitas diri dan ketidak siapan mahsiswa untuk situasi perkuliahan. Melalui bimbingan kelompok ini mahasiswa di latih untuk dapat lebih baik dan membentuk konsep kepercayaan diri yang kuat. Bimbingan kelompok ini menggunakan pelaksanaan dengan berbentuk dinamika yang dimaknai bahwa mahasiswa dilatih untuk memunculkan dirinya sendiri, tanpa diminta ataupun ditunjuk. Melalui pelaksanaan kegiatan mahasiswa mulai mengalami perubahan secara bertahap.

Berdasarkan perubahan yang diamamti selama pemberian perlakuan dan pantauan selama proses perkuliahan TRNG mengalami peningkatan bertahap dalam konsep kepercayaan dirinya, adapun penyebab kepercayaan diri rendah yang dimiliki TRNG karena ketidak siapan TRNG dalam perkuliahan, baik dari segi materi mapun dari segi mental, 
sehubungan dengan pendekatan discovery learning yang diterapkan dalam bimbingan kelompok TRNG melaui wawancara yang dilakukan, TRNG memandah bahwa perlunya suatu persiapan dan suatu analisis terhadap konsep sehingga dirinya akan siap untuk berbicara dan berargumen di dalam perkuliahanan. Subejek penelitian yang mengalami perubahan pesat adlah SCZ karena SCZ memiliki konsep diri yang cukup baik dia memandah bahwa perlunya suatu asosiasi terhadap konsep konsep yang dibahas dalam perkuliahan maupun suatu perkumpulan supaya dapat menyiapkan diri untuk berbicara, bertanya maupun menjawab selama proses perkuliahan. Setelah dieberikan perlakuan aggota kelompok lebih memiliki pemikiran positif terhadap kemampuan dirinya.

\section{Efektifitas Pendekatan Discovery Learning dalam Bimbingan Kelompok Topik Tugas Untuk Meningkatkan Kepercayaan Diri Mahasiswa}

Pelaksanaan pendekatan discovery learning dalam bimbingan kelompok untuk meningkatkan kepercayaan diri mahasiswa diberikan melalui delapan perlakuan dan topik tugas yang diberikan adalah permasalahan yang relevan yang dialami oleh sebagian besar anggota kelompok. Pada proses perlakuan pendekatan discovery learning dalam bimbingan kelompok, memperhatikan tahap-tahap pelaksanaan bimbingan kelompok. Tahap yang dilakukan terlebih dahulu yaitu tahap pembentukan dengan tujuan anggota kelompok paham akan kegiatan dan mengenal baik anggota kelompok kegiatan layanan tersebut, sehingga anggota kelompok dapat mengerti alur kegiatan dan dapat secara terbuka dan suka rela untuk mengikuti kegiatan layanan bimbingan kelompok. Pada tahap ini peneliti membuat setting tempat duduk senyaman mungkinsehingga anggota kelompok dapat mengikuti proses kegiatan dengan baik Selanjutnya tahap peralihan, disana adalah suatu jembatan penghubung akan tahap berikutnya apabila tahap awal berhasil maka dalam tahap peralihan akan muncul suatu bentuk dinamika kelompok yang menunjukkan anggota kelompok siap untuk tahap berikutnya. Selanjutnya tahap kegiatan, dimulai dengan pemberian topik kepada anggota kelompok yang disebut juga dengan topik tugas. Pada tahap ini anggota kelompok saling berbagi informasi dan bertukar fikiran, saling membantu dan menerima, saling menguatkan dan saling berusaha untuk memperkuat rasa kebersamaan (prayitno, 1995).

Pada tahap ini dengan memberikan topik tugas yang dibicarakan dalam bimbingan kelompok terdapat enam topik tugas yang diberikan, topik setiap pertemuan berbeda-beda. Dalam pembicaraan tiap-tiap topik, diarahkan anggota kelompok untuk menggali dan menemukan sendiri jalan keluar setiap topik yang dibahas dengan pendektakan discovery learning. Menurut Salmon (2012:4) dalam pengaplikasiannya model Discovery learning mengembangkan cara belajar siswa aktif dengan menemukan sendiri, menyelidiki sendiri, maka hasil yang diperoleh akan tahan lama dalam ingatan, Serta posisi guru di kelas sebagai pembimbing dan mengarahkan kegiatan pembelajaran sesuai dengan tujuan. Hasil dari pemberian enam kali perlakuan menunjukkan peningkatan kepercayaan diri mahasiswa. Jika dilihat dari hasil Postest kepercayaan diri anggota kelompok mengalami peningkatan yang tinggi, pada awalnya dari pretest terlihat nilai rata-rata kepercayaan diri anggota kelompok 77,5 setelah diberikan perlakuan meningkat dengan 24,3 , sehingga nilai rata- rata Postest kepercayaan diri menjadi 101,8. Dalam bimbingan kelompok anggota kelompok aktif dalam membahas topik yang di munculkan dan pemimpin kelompok sebagai pengatur jalannya bimbingan kelompok, ini sejalan dengan pendekatan discovery learning dimana anggota kelompok menjadi pusat pembelajaran, anggota kelompok diarahkan untuk menemukan sendiri kelemahan kelemahan dalam diri dan upaya untuk keluar dari permasalahan itu. Hasil yang didapat adalah anggota kelompok paham akan masalah yang dialaminya sesuai dengan topik yang dibahas, dan anggota kelompok memuncukan berbagai alternatif jalan keluar dari masalah tersebut. Pemahaman anggota kelompok akan dirinya akan membuat kepercayaan dirinya juga meningkat, sebagaimana muhammad (2016) mengatakan bahwa jika tingkat pemahaman meningkat maka tingkat kepercayaan diri juga meningkat.

Secara ringkas dari beberapa topik yang dibahas dalam tahap kegiatan bimbingan kelompok kemajuan yang terjadi sehubungan dengan kepercayaan diri berbicara di kelas, sebagai berikut: 
1. Berkurang rasa grogi ketika berbicara di dalam kelas/diskusi

2. Berkurangnya perasaan takut untuk bertanya

3. Tumbuhnya prasangka positif ketika ada respon dari orang lain

4. Menyadari bahwa ketika menjawab pertanyaan akan muncul salah dan benar dan hal itu akan menjadi pelajaran untuk menggali kekurangan

5. Dengan menyadari potensi diri muncul pemikiran bahwa jika berfikir bisa melaksanakan maka hal itu bisa terjadi.

Setelah diberikan beberapa perlakuan dengan topik yang berbeda-beda dan di adakan Postest diperoleh kesimpulah bahwa pendekatan discovery learning pada layanan bimbingan kelompok efektif untuk meningkatkan kepercayaan diri mahasiswa.

\section{KESIMPULAN}

Penelitian ini menunjukkan bahwa terdapat pengaruh pendekatan discovery learning dalam bimbingan kelompok topik tugas untuk meningkatkan kepercayaan diri mahasiswa. Seluruh sampel dapat meningkatkan skor angketnya dengan cukup signifikan, disamping itu juga mampumeningkatkan kepercayaan dirinya. Peningkatkan skor tersebutmenyatakan ketepatan hipotesis penelitian dan menandai keefektifan layanan bimbingan kelompok menggunakan pendekatan discovery learning dalam meningkatkan kepercayaan diri mahasiswa. 


\section{REFERENSI}

Aisyah, N. (2013). Pola Asuh Demokratis, Kepercayaan Diri dan Kemandirian Mahasiswa Baru. Jurnal Psikologi Indonesia, 2(2), 108-121.

Fiorentika, K., Santoso, D.B., \& Simon, I. M. (2016). Keefektifan Teknik Self-Instruction untuk Meningkatkan Kepercayaan Diri Siswa SMP. Jurnal Kajian Bimbingan dan Konseling, 1(3), 104-111.

K, S. (2011). Efektifitas Penggunaan Teknik Permainan dalam Bimbingan Kelompok untuk Meningkatkan Percaya Diri Siswa. Jurnal Penelitian Pendidikan, 11(2), 127-138.

Marjanti, S. (2015). Upaya Meningkatkan Rasa Percaya Diri Melalui Konseling Kelompok bagi Siswa X IPS 6 SMA BAE Kudus Tahun Ajaran 20014/2015. Jurnal Konseling GUSJIGANG, 1(2).

Muhammad, N. (2016). Pengaruh Metode Discovery Learning untuk Meningkatkan Representasi Matematis dan Percaya Diri Siswa. Jurnal Pendidikan Universitas Garut, 9(1), 9-22.

Prayitno. (1995). Layanan Bimbingan dan Konseling Kelompok. Jakarta: Ghalia Indonesia.

Ramadhani, E. (2016). Efektivitas Layanan Informasi Menggunakan Pendekatan Discovery Learning dalam Meningkatkan Aspirasi Karier Siswa. Tesis tidak diterbitkan. Prodi S2 BK FIP UNP.

Ramadhani, E. \& Sari K. (2018). Efektivitas Layanan Bimbingan Kelompok Menggunakan Pendekatan Discovery Learning untuk Mengurangi Prokrastinasi Akademik Mahasiswa Mengerjakan Skripsi. Jurnal Wahana Didaktika, 16(02).

Suryosubroto. (2009). Proses Belajar Mengajar di Sekolah. Jakarta: Rineka Cipta. 